\title{
Introduction: music among the bibliographic disciplines
}

Kate van Orden

\section{Details, details}

We begin with an asterisk. Sit down at your computer, open a window in your web browser and go to www.vdm.sbg.ac.at, the Verzeichnis deutscher Musikfrühdrucke database. Now type in a search term. Given my current scholarly interests in the geographical reach of the French chanson, my first search on the $v d m$ database was for 'Clément Janequin'. Joy! Up popped three anthologies in which Janequin's name appears:

Sigmund Salminger, ed., Selectissimae necnon familiarissimae cantiones (Augsburg: Melchior Kriegstein, 1540)

Trium vocum cantiones centum (Nuremberg: Johann Petreius, 1541)

Hans Neusidler, ed., Das ander Buch. Ein new künstlich Lauten Buch (Nuremberg: Julius Paulus Fabritius, 1549).

Drilling down into the details of the Selectissimae necnon familiarissimae cantiones brought up the page shown in Figure I.1, and near the end of the entry, following identifications of the typographic materials, a bibliographic description, list of composers and information about the book design, with accompanying illustrations to the right, stands a list of surviving copies, each linked to individual descriptions that contain further details of provenance, bindings and - where relevant - other items bound with the title in tract volumes.

Here are the asterisks, small and discreet, easy to miss if you rush onward into the pages with detailed descriptions of each surviving copy: *A-Wn, *D-Mbs, ${ }^{*} \mathrm{D}-\mathrm{Ngm},{ }^{*} \mathrm{D}-\mathrm{W}$. These stars merit our attention, for each represents the work of a scholar who examined a copy of the Selectissimae necnon familiarissimae cantiones. Creating this entry involved consulting books in Vienna, Munich, Nuremberg and Wolfenbüttel to refine the rudimentary information available in RISM. Globally, the results are significant: the $v d m$ adds almost hundred new editions to our knowledge of music printing before 1550, and adds many exemplars to those cited in RISM.

Like footnotes, endnotes, stars and daggers, these asterisks reference a backstory: bibliographers verified the status of every known copy of the Selectissimae necnon familiarissimae cantiones, selected one, A-Wn SA.78.F.32, as the 'autopsy' copy, and described it with forensic precision. This insistence on providing detailed descriptions of individual book copies represents a sea change by comparison with RISM, one that merits pausing for reflection, for it marks a radically new attitude towards descriptive bibliography itself. Back when RISM was launched in the 1950s, the library sigla that accompanied each entry were a blunt tool that allowed scholars to know where to request a microfilm or how to 


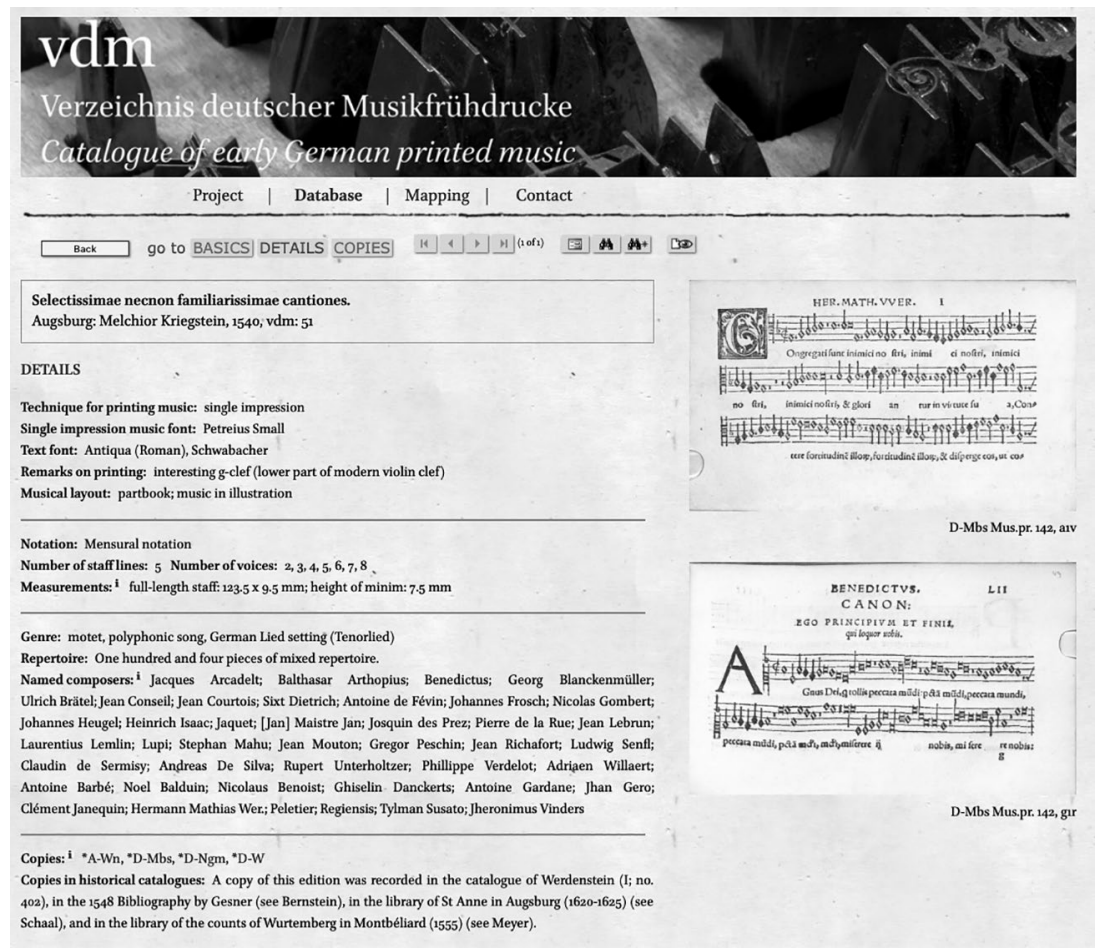

Figure I.1 Verzeichnis deutscher Musikfrühdrucke database, www.vdm.sbg.ac.at, accessed 15 June 2019, screenshot for the search 'Clément Janequin'.

plan a summer research trip. They mapped potential research trajectories in a most practical way, and I certainly remember following their leads back in the day to the British Museum, Bibliothèque nationale de France or the Museo Civico di Bologna, where I spent warm hours in unclimatised reading rooms scoring up chansons.

But the impression given by RISM, and precisely what the $v d m$ so effectively dispels, is that individual book copies are largely the same. From the $v d m$, hidden editions emerge, new titles are discoverable in tract volumes, and the connectedness of surviving books to one another can be charted with astonishing results. Patterns of dissemination, ownership and survival come into focus, and the material histories of printed books begin to reveal their individuality. We need to only click down into the wealth of details and onward to the digital facsimiles linked to the $v d m$ database.

The essays in this volume chart the research trajectories that emerge from next-generation resources like the $v d m$ and the extraordinary digitisation projects that are giving scholars direct access to high-resolution scans of music books. Their critical approaches privilege strains of material history more familiar to musicologists from manuscript studies, and the results bring into focus a number of falsehoods about early printed books that originated in historiographic oppositions between manuscript and printed production, which characterised manuscripts as singular and unique and printed books as mass produced and 
standardised. By subjecting surviving copies of printed music books to the same detailed scrutiny traditionally reserved for music manuscripts, these essays reveal some startling corrections that - taken together - suggest that musicologists have underestimated numbers of reeditions, overestimated the scope of distribution and misjudged the extent to which printing standardised musical repertories. These essays consistently draw attention to the fragility of music printing in ways that depend on a deep appreciation of the physical labour of the print shop; the intractability of lead, paper, vellum, leather and wood; and the profound dialectics of value and valuation that can be recovered from sustained consideration of reprints, survival rates, privileges, capital investment and readers. In sum, they put descriptive bibliography into dialogue with philosophies, ideologies and myths of printing and print culture.

This introduction takes the disciplinary exchanges between descriptive bibliography and histories of 'print culture' as a point of orientation. In doing so, my aim has been to show how this volume both contributes to broader debates and moves beyond them. Certainly the fields of descriptive bibliography and cultural history have been intertwined since the emergence of book history and studies of 'print culture' in the 1980s: Donald F. McKenzie's field-defining Bibliography and the Sociology of Texts (1985) worked to show how 'the material form of books, the non-verbal elements of the typographic notations within them, [and] the very disposition of space itself' have an expressive function in conveying meaning that cannot be set aside by textual critics and literary historians. ${ }^{1}$ In 1994, Roger Chartier famously followed up with the daring proclamation that 'There is no text apart from the physical support that offers it for reading (or hearing) ${ }^{\prime}{ }^{2}$ In these studies and those that took up their calls, descriptive bibliography and histories of print and printing were mobilised in new, more densely social and cultural accounts of objects and oeuvres. At the same time, some bibliographers resisted the claims of book historians, seeing in them the same celebratory rhetoric that had surrounded printing from its very inception.

These broad debates continue to polarise scholarship, and I address them in two steps. In the following section, I explore the 'Myths of Mass Communication' cited by critics of book history, and elucidate the ways this volume characterises the new readerships generated by the commercial production of printed music. What emerges from the studies collected here is a fine-grained appreciation of the factors that conjoined to limit production and dissemination. Our authors reveal the extent to which music printing was local and relatively small in scale, something addressed in the section on 'Materialities', which considers the immobility of printed matter and physical obstacles to cultural transfer. This is not to say, however, that printing had no effect at all on repertorial circulation and consumption. A third and final section, 'Mobilities', zooms back out to consider with fresh eyes the cultural reach of printed music and its distinctiveness as a driver of changing tastes. What becomes clear from this overview is the deftness with which the contributions to Early Printed Music and Material Culture in Central and Western Europe build on musicology's strengths in source studies even as they stake out new histories that move beyond the polarities evident in other fields between descriptive bibliography and cultural histories of the book.

\section{Myths of mass communication}

Printing has long been taken as a prime medium of cultural transmission, a technology perfectly designed to circulate knowledge, beliefs and cultural forms like literature and music. The Renaissance recovery of classical texts, the Reformation and the Scientific Revolution: no discussion of these movements is complete without some account of printing. 
Sociologies of print like the 'communications circuit' first modelled by Robert Darnton and subsequently enhanced by Thomas Adams and Nicolas Barker worked to capture the dynamics of accelerating cycles of production and consumption with strong implications for increasing literacy, readerships and territorial expansion, and a generation of scholars has avidly followed these methodological leads. ${ }^{3}$

The corollary, often asserted rather than argued, is that print was a 'mass medium' and international in scale. Even credible scholars quickly fall victim to startling claims that printed books allowed for transparent communication across time, space and cultures, cohering communities of faceless masses into publics and nations. ${ }^{4}$ In The Gutenberg Galaxy: The Making of Typographic Man (1962), Marshall McLuhan famously proclaimed that print staged the rise of modern nationalism by centralising the use of language. ${ }^{5}$ Inspired by McLuhan's media theories, Elizabeth Eisenstein subsequently described what she called a 'communications shift' 'encompassing the entire world' in her landmark study The Printing Press as an Agent of Change: Communications and Cultural Transformations in Early Modern Europe (1979). ${ }^{6}$

Fact can swiftly be left behind when the subject turns to the cultures that coalesced around print: in Imagined Communities: Reflections on the Origin and Spread of Nationalism (1985), Benedict Anderson depicted printing as international and presses operating on a 'colossal scale' that 'saturated' European publics with books and newspapers: the 'spread' of his title depended on print. ${ }^{7}$ Yet studies like Imagined Communities hardly theorise the mobility on which their explanations depend. Production and distribution are a free-forall, in which printed sheets fly like magic carpets transmitting knowledge and culture unimpeded to all corners of the globe. Or to use a more modern metaphor, print is likened to broadcast television, beamed directly into households, cafés and bars with the flick of a switch. These triumphant narratives are gratifying to repeat, but they have the pernicious effect of naturalising the relationship between printing and cultural mobility, obscuring the fragility of the new technology and the limits of its cultural reach.

Intoxicating as they are, histories like Anderson's are difficult to square with the evidence of source materials. Those who dirty their hands working with early books rarely buy into such bold rhetoric, and outside of musicology, bibliographers - who specialise in the particular - have proved staunch critics of big media theories. In his scathing book, The Myth of Print Culture: Essays on Evidence, Textuality, and Bibliographic Method (2003), Joseph Dane argued that Lucien Febvre and Henri-Jean Martin grossly overestimated print-runs and numbers of editions in L'apparition du livre, thereby inciting generations of hyperbolic claims of a print revolution that swept Europe. ${ }^{8}$

As musicologists well know, printing made no sense for entire genres such as opera and orchestral repertoire, even into the era of lithography. The partbooks examined by John Milsom in his chapter on printed music papers vividly illustrate the persistence of manuscript production in the letterpress era, and their mongrel form - part manuscript, part print - attests to the convenience of copying music in numerous circumstances. The slow pace at which polyphonic music printing evolved, lagging half a century beyond Gutenberg's invention, shows the resistance of polyphonic repertoire to popularisation before around 1540, when the market for all sorts of printed recreational materials finally began to gain ground. ${ }^{9}$ Even so, in the chapter that closes this volume, Iain Fenlon elucidates the economic, social and geographic pressures that prevented music printing from succeeding in sixteenth-century Seville, where printers struggled to survive crises like paper shortages and printing errors in the books witness the stressful circumstances of their production. 
Negative histories such as Fenlon's set important boundaries, forcing into view the localness of printed production and the limits of dissemination in ways that contradict the astronomical rhetoric that made McLuhan's galactic characterisation of Gutenberg's invention such a bestseller in the age of Sputnik and the Apollo space programme. Numerous studies in this volume effectively restrict the claims that can be made for the cultural reach of print even as they stake it out: Moritz Kelber's study of Georg Rhau's presses in Wittenberg shows Rhau authorising his books as explicitly Lutheran by including prefaces by Martin Luther and Philipp Melanchthon, emblazoning them with Electoral Saxon devices, and - after 1542 - decorating the title pages with emblems of the reformers. Unlike southerly printers in Augsburg and Nuremberg, who served mixed audiences of Catholics and Protestants, Rhau laid claim to the special status of Wittenberg even as he limited the market for his books, despite the cross-confessional nature of the repertoire. In her chapter on distribution of music printed by the Officina Plantiniana in Antwerp, Louisa Hunter-Bradley provides a stark, data-rich analysis of the musical output of Christophe Plantin's press that reveals just how few book copies entered distribution networks designed to reach distant markets. For Plantin's super-sized choirbooks, such as the Octo Missae (1578) of George de La Hèle, initial sales might be quite feeble: just three dozen for the Octo Missae, and this despite the glorious typography, with newly cut fonts, and heavy marketing with printed posters advertising the publication sent to Paris to boost sales. ${ }^{10}$ Booksellers near Plantin's press tended to take just two or three copies of even the most marketable sets of partbooks for resale in their shops, and major shipments went directly to Frankfurt for the book fair. Mapping the data title per title can account for a significant share of book copies in ways that contradict claims of mass dissemination to avid consumers across Europe and the world.

Outside of musicology, analogous studies rooted in descriptive bibliography, archival research and economic history have been used to shut down cultural histories of the book, but we should be wary of pitting bibliography against the cultural studies it can support. Indeed, critiques objecting to cultural studies of print have been advanced virtually as long as the studies they decry: Elizabeth Eisenstein's Agent of Change received repeated drubbings, even recently, and Joseph Dane followed up on The Myth of Print Culture with further salvos in his Blind Impressions: Methods and Mythologies in Book History (2013). ${ }^{11}$ There he argues that book history is entirely self-referential and even egotistical:

As bibliographers or book historians, we perform our work by changing the function of the objects we study. We rarely pick up an Aldine edition to read one of the classical texts it contains. No one reads the Bible in Gutenberg's version [...] and no one learns Latin by reading Donatus. Print culture, under this notion, is not a medium for writing or thought but a historical object of study; our bibliographical field, our own concoction, becomes the true referent of the objects we define as its foundation.

[...] The privileged beings in these histories are not those who produced the textual and bibliographical material (book-makers and writers), the privileged beings are bibliographers, particularly contemporary ones, and most specifically ourselves. Book history? It is us. ${ }^{12}$

The oppositional and quasi-personal tone of such attacks may, in themselves, explain much about musicology's relative disengagement from these debates, which are ageing quickly and invite more judicious interventions of the sort collected here, which employ methodologies adopted liberally from an array of fields, depending on the books and book cultures under consideration. 
Dane, we should note, writes from a position of disciplinary privilege rarely enjoyed by music bibliographers. He might be 'picking up' an Aldine edition, Gutenberg Bible or a Shakespeare folio (another of his examples), but musicologists are often lucky just to find one complete set of flimsy sixteenth-century partbooks remaining from an entire edition. If anything, the survival rates for printed books of music align sooner with riff-raff books of lyric poetry and chivalric romances than they do with the collectable tomes Dane considers natural examples for his arguments about scholarly self-absorption.

For instance, the Aldine press printed 1,030 copies of Baldassare Castiglione's Cortegiano in royal folio, of which 147 copies survive, and recent censuses register 228 extant copies of the Shakespeare first folio of 1623 to survive from a print-run of $750 .{ }^{13}$ The survival rates for those editions are $14 \%$ and $31 \%$ respectively. Yet compare these figures to the dismal survival rate of Andrea Antico's royal-sized folio choirbook, the Liber quindecim missarum (Rome, 1516), which was issued in 1,008 copies. According to RISM, only seventeen survive complete. That gives a survival rate of $1.6 \%$. And, as Royston Gustavson shows in his chapter, such comparatively buoyant rates of survival diminish rapidly once the books become smaller, both in terms of page size and number of leaves. My own estimates for chansonniers place survival rates well below 1\%, and Tim Carter estimates that for the Italian secular music he studies, $15 \%-20 \%$ of titles are now lost entirely. ${ }^{14}$ In our field, the discovery - thanks to the $v d m$ - of several unknown copies of music books represents far more than an infinitesimal statistical shift in census numbers: the locations of missing Tenor partbooks to Christian Egenolff's Cantiones vocum quatuor [1536] and Cantiones vocum trium [1536] are major finds of precious unica. ${ }^{15}$ Partbooks like the one shown in Figure I.2, roughly printed in sextodecimo, are precisely those that tended to suffer the most destruction. But they were likewise the most affordable formats and most representative of the broad reach of songs like these chansons. As performance parts, music books were used hard by singers and players and used up quickly.

It is against the background of performance that the editions discovered by Martin Ham should be read. His study of the output of Tylman Susato's press reveals second and third editions of Susato's motet series that survive in such fragmentary states they eluded Ute

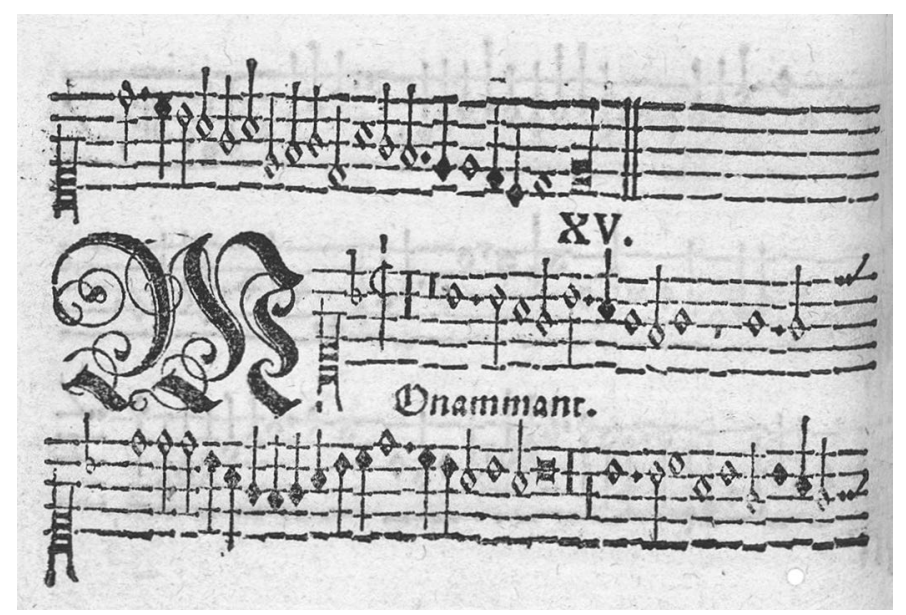

Figure I.2 Cantiones vocum quatuor (Frankfurt: Christian Egenolff, [1536]), vdm 25, Discantus, fol. $\mathrm{Hh} 8^{\mathrm{v}}$.

Source: Paris, Bibliothèque nationale de France, RES VM7-504/1 (Source gallica.bnf.fr). 
Meissner's detection when she catalogued Susato's output. Even given his extraordinary sleuthing based on analysis of typographic materials, Ham concludes that he may still be underestimating Susato's productivity in the 1550s, when reprints accounted for much of Susato's activity. ${ }^{16}$ Maria Schildt's study of the Phalèse press from 1629 to 1675 identifies seventy-five ghost editions, over one-third of the output now known to us today.

The trio of Libri missarum studied by Carlo Bosi, printed by Johann Petreius (Nuremberg, 1539), Hieronymus Formschneider (Nuremberg, 1539) and Georg Rhau (Wittenberg, 1541), all survive in fair numbers, by contrast, at least by comparison with the cases just cited. ${ }^{17}$ Hans Ott, who edited and published the masses printed by Formschneider, stated in his dedication that by reprinting these musical 'monuments', he aspired to preserve and disseminate them for posterity. The sense of urgency might have been palpable, given the date of the music: Petreius relied on a copy of a Petrucci edition from the turn of the century for some of his material, while Georg Rhau apparently had a copy of Antico's Liber quindecim missarum to hand.

The upshot is that in musical repertoires, the very absence of books can point to their success: Royston Gustavson shows in his analysis of a precious Montanus \& Neuber catalogue from 1560 that the correlation between the size of a book and the survival of copies is direct, with larger formats and thicker volumes that required sturdier bindings faring better than smaller books and partbooks, some of which could easily have been left in paper covers. Moreover, he posits that attrition for books in duodecimo and smaller formats was swift, beginning shortly after publication, all of which positions musicological scholarship very much on the broader side of cultural history and the new histories of reading aloud that are working to see books in action. ${ }^{18}$ At the most ephemeral end of the scale are occasional works like the motet celebrating the Saxon city of Annaberg discovered by Moritz Kelber, who posits that the printing of single works of polyphony in half-sheet pamphlets or on broadsides may have been more common than we realise. Calculations of cultural value in these repertoires thus need to account for the inverse relations linking survival rates to pricing, sales and consumption, even as some specific editions, like the Melopoiae (Augsburg, 1507) studied by Elisabeth Giselbrecht, defy generalisations.

Dane objects to the abstractions book historians often make from individual bookcopies in the move from descriptive bibliography to studies of 'print culture', but scholars of songs like the one depicted in Figure I.2, Ninot le Petit's Mon ammant, cannot justifiably ignore the critical tools cultural histories of the book can bring to the table. ${ }^{19}$ For vernacular genres, printed partbooks are often the only substantial material evidence that survives, fragile though it may be. Musicologists are not busy deliberating whether to read the Bible in Gutenberg's edition or one from another press: musicologists are still working to score up any legible edition whatsoever. In musicology, primary research in descriptive bibliography has always overlapped with repertorial study and cultural history. Perhaps it is because music historians so often trek to libraries in search of that missing partbook, perhaps because music notation is such a graphic art and needs to be seen or perhaps because musicology is at a different point on the curve from literary studies when it comes to bibliographic control and editing repertoire: for whatever reason, it remains the case that scholars of early music are often de facto book historians.

One credo of the cultural histories emerging from bibliography is that books are loaded with social information, and this might be especially true for music books, given the communal performances they script and the prevalence of tract volumes that can reveal the collecting strategies of early owners. Decades ago, Natalie Zemon Davis encouraged scholars to 'consider a printed book ... a carrier of relationships', ${ }^{20}$ and one study in this volume that 
responds to that challenge is Elisabeth Giselbrecht's Rezeptionsgeschichte of the Melopoiae (Augsburg, 1507). Taking advantage of its extraordinarily flush rate of survival - twenty-five copies in all - she elucidates what can be discerned about its publics by identifying its early owners and their interests, which ranged from collectors like Hartmann Schedel, whose copy was part of a massive library of universal subject matter, to lesser-known individuals who used their copies as a place to stash other ode settings and lyric poetry. Equally textured is Beat Föllmi's characterisation of Strasbourg editions from the beginning of the Reformation to the end of the Interim in 1555, a period that witnessed fifty editions of sacred songbooks, many initiated by enterprising preachers. Föllmi stresses the diversity of these editions, which include German hymnbooks, rhyming French psalters and hymns of the Bohemian Brethren, the last commissioned by Katharina Zell, wife of Münster preacher Matthäus Zell. By reading their contents against local (shifting) liturgies and their target audiences, Föllmi recovers a resonant soundscape of musical devotion, evangelical preaching and spiritual singing in the city's homes and workplaces.

\section{Materialities}

Investigations like the aforementioned, which tangle with questions of audience, public, marketing, pricing and reception through the optic of specific editions, local cultures and individual print houses, consistently knock up against the material pressures that constrained the establishment of presses and distribution of printed matter. When charted through critical bibliography, studies of printed matter clarify the extent to which books are rooted in the particular, deeply cultural (in the original sense of 'culture' as derived from the cultivation of plants) and far less of a media revolution than McLuhan would have it.

Printing is heavy business, and presses are immobile by design. Projects that map the location of printing presses with animated timelines, such as The Atlas of Early Printing at the University of Iowa, produce the superficial impression that printing quickly spread across Europe from its origins in Strasbourg and Mainz and its first large footholds in Cologne, Basel, Nuremberg, Augsburg, Venice, Rome, Naples and Paris, as though presses themselves were on the go. ${ }^{21}$ Yet the dazzling data can also be read differently, as evidence of inadequate distribution networks and the localness of production. Even the raw materials of book manufacture could not be had just anywhere in Europe. High-quality paper made from linen rags could only be produced in places with running water to power the hammers that pounded the rags into mulch, clean water to wash the mulch, and quantities of discarded clothing, preferably fine white linens. Thus, paper mills were initially concentrated in Southern climes, where linen clothing was more common (as opposed to the woollen clothing worn in Northern Europe), and likewise near large urban areas..$^{22}$ In the sixteenth century, Venetian printers imported paper from Padua, Treviso and Friuli; most of the paper for Christophe Plantin's presses in Antwerp came from French mills, many in Normandy and Champagne, since the paper manufactured in the Low Countries was of inferior quality (it probably contained a large proportion of hemp); and when a press was set up in Mexico City in 1540, all the raw materials came from Europe: paper, type, machines and ink. ${ }^{23}$ The Sevillano printers studied by Iain Fenlon imported their paper from Italy.

Type foundries, too, were fewer in number than presses, and tended to be concentrated in centres of printing, since lead type was extremely heavy, and foundries melted down broken and worn type for recasting. Even large enterprises like Plantin's used type cast by local foundries. Some of these suppliers specialised in type design, cutting the steel 
punches that were used to make the type matrices. Prominent foundries also stocked matrices of typefaces cut by others, thereby enlarging the range of types they sold. Matrices could be used for decades and were bought and sold on an international scale that is traceable through the production of individual presses. Laurent Guillo has shown, for instance, how a type first used by Petreius in Nuremberg came to be employed by music printers in Paris, Venice, Augsburg, Kraków and elsewhere in Europe. ${ }^{24}$ It was still being used in Stockholm as late as 1733, 200 years and 15,000 km from its point of origin. Highly coveted for its beauty, legibility and adaptability to a variety of uses, this font was used by Parisian printers for their larger oblong quarto partbooks and for the landmark publication of the Balet comique de la Royne (Paris: Le Roy \& Ballard, 1582). The Le Bé type foundry in Paris, which supplied this type, persisted for centuries. ${ }^{25}$ One of the largest German foundries, the Egenolff-Berner-Luther type foundry in Frankfurt, was still offering sixteenth-century italics cut by the French type designer Robert Granjon in their specimen catalogue of $1745 .{ }^{26}$ That foundry, begun around 1555, capitalised on the success of Christian Egenolff, who expanded his printing business into a vast enterprise geared towards profit and control, including ownership of a paper mill and a strong presence at the Frankfurt book fair, which was likewise a trading post for matrices.

Egenolff's music books certainly fell to the smallest end of the scale: editions like the Cantiones vocum quatuor depicted in Figure I.2, a rough sextodecimo reprint of chansons from Petrucci's Canti B, were designed for quick production, swift sale and maximum profit. ${ }^{27}$ Unsurprisingly, Egenolff's music fonts were not embraced by other printers: the long stems and other elements that extended beyond the rectangular body of the type were susceptible to buckling and breaking, and the staff lines were badly misaligned. Punchcutting required true artistry and exactitude, much like gold work and jewellery-making. (It took several hours to cut a punch, and several hours more to justify the matrices to make sure that the resulting types were well aligned, and it was especially difficult to design and cut small fonts and highly inclined italics and civility types with flamboyant kerns.) The most renowned punch-cutters often had highly international careers: Robert Granjon worked in Paris, Lyons, Antwerp and finally Rome. One gets the sense that punch-cutting, which flourished around 1550, was an industry with a brief arc, and that successful artisans moved on after they exhausted opportunities in place after place. Foundries guarded their punches like original works of art, which they are, and as is evident from the selection of typefaces available on Adobe and other typesetting software, the designs of Granjon, Claude Garamond and other sixteenth-century artists have retained their place as paragons of typography even into the digital age.

Studies of music typography are gradually revealing the extraordinary mobility and longevity of some fonts, and more investigation will repay the scholars who undertake it. Iain Fenlon observes in his chapter that even major presses in Spain did not possess punches and that printers regularly shared typographical materials. These collaborative relationships among printers made special sense in the case of music printing, which was a niche endeavour; thus, it comes as a surprise that Andrea Lindmayr-Brandl failed to find evidence of such practical exchanges in her study of multiple-impression printing in German-speaking lands. Despite the concentration of music presses in cities like Augsburg, the pioneers of polyphonic music printing there worked independently, sometimes using newly created fonts for but a single edition before shelving music projects entirely. Overall, initial production was spotty and uneven in quality.

Even after music printing took firm root, obstacles continued to pertain. Leendert van der Miesen shows that even in a printing capital like Paris, which by the turn of the seventeenth 
century had a venerable legacy of music printing, few options might be available to those who wished to bring music to light. The music theorist Marin Mersenne described the printing of the Harmonie universelle as three years of 'very hard work', lambasted Parisian booksellers as 'petty tyrants' and lamented that manuscript publication might have produced a better result. At the root of Mersenne's problems was the royal monopoly held by the firm of Robert II Ballard (Mersenne had no other choices), yet such complaints also stand as a reminder that despite its commercial viability, single-impression typography remained relatively unsuccessful from a graphic standpoint, marred as it was by broken staff lines. For this reason, multiple-impression printing and xylography persisted throughout the sixteenth century, even after the development of copperplate engraving, which once and for all solved the problem of graphic continuity essential to music notation, but at a price. ${ }^{28}$

This overview of paper-making, punch-cutting, type foundries and design problems illustrates the production challenges faced by music printers even as it charts the international scale of the solutions required to overcome the restricted availability of paper, typographic materials and skilled craftsmen. Further weight could be added to this material history with analyses of how printers sourced vermilion to make red ink (it was dealt by spice merchants), and where foundries procured lead, tin and antimony for the casting of type, but the point should be amply clear: both local and global forces were at play in the economies of the print shop.

Material history, by paying due to the very intractability of matter, also calls attention to the ambition of those artists, pressmen and entrepreneurs who developed the new industry, the men and women whose hard work sublimated linen, metals and oily ink into printed sheets. Printing required manual, intellectual and capital investments that might take years to return a profit. These financial factors led some printers and publishers to seek privileges to protect their ventures, a subject investigated by Grantley McDonald and Stephen Rose. McDonald and Rose clarify the legal origins of printing privileges, the history of book privileges in the pre-print era and the likeness of printing privileges to patents, which were granted for new techniques for processing silk, manufacturing glassware, harnessing waterpower to operate machinery and so forth. For instance, the very first privileges awarded to music printers - those accorded to Ottaviano Petrucci and Andrea Antico by Pope Leo X covered contrasting technologies: double-impression typography and xylography, respectively. In both of those originary cases, proprietary claims of 'authorship' indisputably went to those who made the books in the most literal sense, for it was the printers who sank capital, ingenuity and long labour into their manufacture, to paraphrase Antico's own description of the effort expended in bringing the Liber quindecim missarum to light. ${ }^{29}$

Eventually privileges were accorded directly to composers (Orlando di Lasso is a case in point), but these were exceptions, and undue focus on them has confused the nature of privileges with more modern forms of ownership such as copyright, intellectual property and artistic product. ${ }^{30}$ Perhaps the most striking conclusion of McDonald and Rose's chapter is that prior to 1550, printers in German-speaking lands rarely sought privileges, which were costly to obtain for their already unique goods: less than $0.5 \%$ of the editions in the $v d m$ carried privileges, which should caution historians against reading much value into them in the first decades of commercial music printing.

\section{Mobilities}

Having begun with an asterisk, let us end with a subject usually relegated to a footnote or consigned to the obligatory list of 'other sources' in modern editions: the reprint. Across the 
studies in this volume, the prominence of reprints is so striking as to stake out a prime area for future research: the masses of Josquin des Prez are reprinted decades after his death, arrangements of Italian madrigals are printed in Seville, and Peter Schöffer the Younger was granted a special privilege to protect the Cantiones quinque vocum selectissimae (Strasbourg, 1539), a book of motets he had gone to great lengths to source in Italy. ${ }^{31}$ Such a list, which could be multiplied, is thought-provoking in its denial of geographic and chronological boundaries. Indeed, my own search of the $v d m$, with which we began, turned up French chansons of Janequin reprinted in Augsburg and Nuremberg. Music printed at some remove from a composer's activities has long been relegated to secondary status by editors in search of authoritative readings, and in some cases, the late appearance of a work in print has pitched it over into the 'dubious' column of works lists. About a third of Josquin's chansons have been discredited for their late appearance in surviving sources, for instance, which has significantly quashed scholarship on these songs, elegant though they may be. ${ }^{32}$

Repertorial studies that begin from the perspective of reprints can help us reset critical agendas: instantly, they reorient research towards reception and consumption, neatly circumventing author-centric historiography and foregrounding a considerable number of sources that newfound bibliographic control is bringing into view. Maria Schildt's contribution to this volume exemplifies the explanatory power that can be leveraged from the second-hand stratum of derivative, knock-off and pirated repertoires. Perhaps not coincidentally, her study also brings female entrepreneurs into view, women with extensive careers like Katharina Gerlach, and others like the wife of Pierre Attaingnant, Marie Lescalloppier, who took the helm of major presses as widows. Schildt examines the output of Madeleine and Marie Phalèse (1629-1675), daughters of Pierre II Phalèse, who inherited the music printing firm from their father and ran it for forty-five years under the imprint 'Heirs of Phalèse'. What can we make of the fact that almost half of the editions issued by the Phalèse sisters contain music by Italian composers? They are full of madrigals, canzoni amorosi, villanelle and balletti like Giovanni Giacomo Gastoldi's best-selling collections for three (1594) and five voices (1591), which proved so popular that after reprinting them multiple times, the Phalèse sisters brought out an edition of the three-voice Balletti with Dutch translations of the lyrics.

The mobility of Italian repertoires and their marketability in Antwerp can help us refract generalisations about the circulation of music into valuable specifics. Read against the backdrop of what we now know about the localness of production, these apparently marginal sources bring within hearing underexplored communities of music-making: immigrants must be accounted for, resident foreigners like the Florentine, Genoese, Lombard and Luccan 'nations' in international centres of trade like Antwerp, and Flemish or Francophone singers who liked a madrigal or two. ${ }^{33}$ Soundscapes emerge as polyglot, culture as mixed. Songs allow us to listen in to the spoken environment of early modern cities, revealing the mobility of people, languages and trade. This is to say, the publics anticipated in the choices of printers were not distant and unbounded, but known and proximate.

Repertorial mobility brings us back to the social and cultural issues with which we began, showing how musicology contributes to both sides of the debates over mass media and how printing did (or did not) internationalise communication. On the one hand, acknowledging the roots and routes of printed material confronts us with the complexity of local cultures and the movement of people, goods and song from place to place along trade 
routes, on military campaigns, to university, and in pilgrimage to holy shrines. Yet careful studies of reprinted repertoires also dial back globalisms - can we really continue to use blanket terms like 'pan-European polyphony'? - and replace them with the pointed analyses musicologists regularly essay in the study of manuscripts, their provenance and recipients. As we dig into the pages of printed music books, we can begin to hear echoes of spoken environments elsewhere silenced in print by the rise of national languages and regulatory agencies like the Accademia della Crusca, founded in Florence in 1583, or the Académie française, founded by royal patent in 1635. In this respect, McLuhan had it right - the linguistic ideologies prompted by reactions to printing did indeed support the uniform centralising forces of modern nationalism. Likewise, the nationalistic arguments of Benedict Anderson's Imagined Communities begin to take on validity when squared with Romantic ideologies of folk music and the myths of ethnic purity so foundational to modern nation-states. The studies in this volume in no way endorse the inflated rhetoric of global (or galactic) communication and top-down cultural policy trumpeted by early media theorists like McLuhan and Anderson. Rather, they represent an important new history 'from below', one that leverages the documentary evidence of printed music books to move beyond production-end histories of composition and deepen our understanding of the people who sang, played, heard and danced to the music coming off presses in Central and Western Europe.

\section{Notes}

1 McKenzie, Bibliography and the Sociology of Texts, 8.

2 Chartier, The Order of Books, 9.

3 Darnton, The Kiss of Lamourette, 107-136; Adams and Barker, 'A New Model for the Study of the Book', 5-44.

4 For one recent celebration of printing as stimulating early modern readers to 'think nationally, internationally, and transnationally while leading decidedly local lives', see the introduction to McElligott and Patten, The Perils of Print Culture, 2-3.

5 McLuhan, The Gutenberg Galaxy, 199.

6 Eisenstein, The Printing Press as an Agent of Change, 277.

7 Anderson, Imagined Communities, 35, 40.

8 Dane, The Myth of Print Culture, 32-35, citing Febvre and Martin, L'apparition du livre, 281, 377, 396.

9 On the commercialisation of recreational books, including music, see Pettegree, The Book in the Renaissance, 151-176.

10 See Vanhulst, 'Suppliers and Clients', 563. For an account of the extraordinary circumstances that led Plantin to publish La Hèle's masses in the first place, see van Orden, Music, Authorship, and the Book, 66-67.

11 For the enduring controversies surrounding Eisenstein's Agent of Change, see the debate organised by Grafton, 'Introduction: How Revolutionary Was the Print Revolution?' and the contributions of Eisenstein, 'An Unacknowledged Revolution Revisited', and Johns, 'How to Acknowledge a Revolution'. More recently, Bacon, Lindquist and Shevlin, 'Introduction', provide a balanced account of the influence of Eisenstein's research.

12 Dane, Blind Impressions, 1-2.

13 See, respectively, Fahy, 'Royal Paper Copies of Aldine Editions', and Rasmussen and West, The Shakespeare First Folios. The appearance of three further copies of the First Folio since Rasmussen and West's catalogue was published in 2012 brings the total of known copies to 235 .

14 See van Orden, Materialities, 88-98, from which this synopsis is drawn, and Carter, 'Music-Selling in Late Sixteenth-Century Florence', 485-486.

15 See Gustavson, 'The Music Editions of Christian Egenolff', and Fallows, 'The Songbooks of Christian Egenolff'.

16 For the standard catalogue of Susato's output, see Meissner, Der Antwerpener Notendrucker Tylman Susato. 
17 The $v d m$ shows: Petreius 15 (2), Formschneider 14 (2) and Rhau 2 (2) (with numbers of incomplete sets in parentheses). The typography of the Petreius and Rhau editions is particularly beautiful, with striking two-colour printing on the title-page of the Rhau and large woodblock initials throughout both editions.

18 See, most recently, the essays in Richards and Wistreich, Voicing Texts, 1500-1800.

19 This chanson is given as 'Mon ami' in Canti C (Venice: Petrucci, 1504). On the contents of this volume, see Bridgman, 'Christian Egenolff'.

20 Davis, Society and Culture, 192.

21 See The Atlas of Early Printing, accessed 17 June 2018, which is based on information compiled from ISTC. See also the mapping tool for early German printed music on the homepage of $v d m$ (https://ispacevm38.researchstudio.at/vdm/).

22 Pettegree, The Book in the Renaissance, 17. For a map of paper mills in Europe to 1500, see The Atlas of Early Printing, and for an excellent account of the manufacturing process before 1800, see Barrett, 'European Papermaking Techniques, 1300-1800', also hosted by the University of Iowa (accessed 17 June 2018).

23 On Venice, see Bernstein, Print Culture and Music in Sixteenth-Century Venice, 34-35; on Plantin, see Voet, Golden Compasses, 2: 22-32, and on Mexico City see Pettegree, The Book in the Renaissance, 266.

24 Guillo, "'Made in Germany"', type 4.

25 On the Le Bé foundry, see Morison, 'L'inventaire de la fonderie Le Bé', and on Granjon, see van Orden, 'Robert Granjon and Music'. The Granjon italics are catalogued in Vervliet, The Palaeotypography of the French Renaissance, 2: 336, 346, 348, 352, 360.

26 Vervliet, The Palaeotypography of the French Renaissance, 1: 88, 172.

27 See Kmetz, 'The Music Books of Christian Egenolff', which analyses Egenolff's output from the financial perspective. Also see Stallybrass, 'Little Jobs', which argues that the lucrative printing of pamphlets and broadsides enabled presses to produce costly editions such as Plantin's polyglot Bible.

28 For some mid-century examples of double-impression music printing and the continued use of woodblocks, particularly in psalters, see van Orden, 'Robert Granjon and Music', 31 note 24.

29 See van Orden, Music, Authorship, and the Book, 30-38, with these lines from Antico's preface at 34 .

30 On Lasso, see Haar, 'Orlando di Lasso', 135, 140, and on the history of intellectual property debates, see Johns, Piracy. Chartier, The Order of Books, 25-59 ('Figures of the Author') provides a textured overview of the intersections of literary ownership, legal prosecution and patronage for the first centuries of printing.

31 See, respectively, the studies in this volume by Carlo Bosi, Iain Fenlon and Grantley McDonald and Stephen Rose.

32 See van Orden, 'Josquin, Renaissance Historiography, and the Cultures of Print', 354-361.

33 See Hoekstra, 'The Reception and Cultivation of the Italian Madrigal', esp. 130-138.

\section{References}

Adams, Thomas R., and Nicolas Barker. 'A New Model for the Study of the Book'. In A Potencie of Life: Books in Society, edited by Nicolas Barker. London: British Library, 1993, 5-44.

Anderson, Benedict. Imagined Communities: Reflections on the Origin and Spread of Nationalism. Revised edition. London and New York: Verso, 2006.

Bacon, Sabrina A., Eric N. Lindquist, and Eleanor F. Shevlin. 'Introduction'. In Agent of Change: Print Culture Studies after Elizabeth Eisenstein, edited by Sabrina Alcorn Bacon, Eric N. Lindquist, and Eleanor F. Shevlin. Amherst and Boston: University of Massachusetts Press, 2007, 1-12.

Barrett, Timothy. 'European Papermaking Techniques, 1300-1800'. In Paper through Time: Nondestructive Analysis of 14th- through 19th-Century Papers. http://paper.lib.uiowa.edu/european.php, hosted by The University of Iowa Libraries (2012).

Bernstein, Jane A. Print Culture and Music in Sixteenth-Century Venice. New York: Oxford University Press, 2001. 
Bridgman, Nanie. 'Christian Egenolff, imprimeur de musique (A propos du recueil Rés. Vm 504 de la Bibl. nat. de Paris)'. Annales Musicologiques 3 (1955): 77-178.

Carter, Tim. 'Music-Selling in Late Sixteenth-Century Florence'. Music E Letters 70 (1989): 483-504.

Chartier, Roger. The Order of Books: Readers, Authors, and Libraries in Europe between the Fourteenth and Eighteenth Centuries, translated by Lydia G. Cochrane. Stanford, CA: Stanford University Press, 1994.

Dane, Joseph A. Blind Impressions: Methods and Mythologies of Book History. Philadelphia: University of Pennsylvania Press, 2013.

Dane, Joseph A. The Myth of Print Culture: Essays on Evidence, Textuality, and Bibliographic Method. Toronto: University of Toronto Press, 2003.

Darnton, Robert. The Kiss of Lamourette: Reflections in Cultural History. Revised edition. New York: Norton, 1990.

Davis, Natalie Z. Society and Culture in Early Modern France. Stanford, CA: Stanford University Press, 1975.

Eisenstein, Elizabeth L. The Printing Press as an Agent of Change: Communications and Cultural Transformations in Early Modern Europe. 2 vols. Cambridge and New York: Cambridge University Press, 1979.

Eisenstein, Elizabeth L. 'An Unacknowledged Revolution Revisited'. American Historical Review 107 (2002): 87-105, 126-128.

Fahy, Conor. 'Royal Paper Copies of Aldine Editions, 1495-1550'. Studies in Bibliography 57 (20042005): 85-113.

Fallows, David. 'The Songbooks of Christian Egenolff'. In NiveauNicheNimbus. Die Anfänge des Musikdrucks nördlich der Alpen, edited by Birgit Lodes. Tutzing: Hans Schneider, 2010, 347-354.

Febvre, Lucien and Henri-Jean Martin, eds. L'apparition du livre. Paris: Éditions A. Michel, 1958.

Grafton, Anthony. 'Introduction: How Revolutionary Was the Print Revolution?'. American Historical Review 107 (2002): 84-86.

Guillo, Laurent. "'Made in Germany". The Dissemination of Mensural German Music Types Outside the German-Speaking Area (and vice versa), up to 1650'. In Early Music Printing in GermanSpeaking Lands, edited by Andrea Lindmayr-Brandl, Elisabeth Giselbrecht and Grantley McDonald. London and New York: Routledge, 2018, 67-83.

Gustavson, Royston. 'The Music Editions of Christian Egenolff: A New Catalogue and Its Implications'. In Early Music Printing in German-Speaking Lands, edited by Andrea Lindmayr-Brandl, Elisabeth Giselbrecht and Grantley McDonald. London and New York: Routledge, 2018, 153-195.

Haar, James. 'Orlando di Lasso, Composer and Print Entrepreneur'. In Music and the Cultures of Print, edited by Kate van Orden. New York: Garland, 2000, 125-151.

Hoekstra, Gerald R. 'The Reception and Cultivation of the Italian Madrigal in Antwerp and the Low Countries, 1555-1620'. Musica Disciplina 48 (1994): 125-187.

Johns, Adrian. 'How to Acknowledge a Revolution'. American Historical Review 107 (2002): 106-125.

Johns, Adrian. Piracy: The Intellectual Property Wars from Gutenberg to Gates. Chicago, IL: University of Chicago Press, 2009.

Kmetz, John. 'The Music Books of Christian Egenolff, Bad Impressions = Good Return on Investment'. In Early Music Printing in German-Speaking Lands, edited by Andrea Lindmayr-Brandl, Elisabeth Giselbrecht and Grantley McDonald. London and New York: Routledge, 2018, 135-152.

McElligott, James and Eve Patten, eds. The Perils of Print Culture: Book, Printing, and Publishing History in Theory and Practice. Basingstoke and New York: Palgrave Macmillan, 2014. 
McKenzie, Donald F. Bibliography and the Sociology of Texts. The Panizzi Lectures 1985. London: The British Library, 1986.

McLuhan, Marshall. The Gutenberg Galaxy: The Making of Typographic Man. Toronto: University of Toronto Press, 1962.

McMurtrie, Douglas C. 'Types and Typefounding in Germany: The Work of Christian Egenolff and His Successors in the Development of the Luther Foundry'. The Inland Printer 73 (1924): 564-569.

Meissner, Ute. Der Antwerpener Notendrucker Tylman Susato. Eine bibliographische Studie zur niederländischen Chansonpublikation in der ersten Hälfter des 16. Jahrhunderts, 2 vols. Berliner Studien zur Musikwissenschaft, xi. Berlin: Merseburger, 1967.

Morison, Stanley. L'inventaire de la fonderie Le Bé selon la transcription de Jean Pierre Fournier. Paris: André Jammes, 1957.

Pettegree, Andrew. The Book in the Renaissance. New Haven, CT and London: Yale University Press, 2010.

Prickman, Greg, Andrew Holland, and Robert Shepard. The Atlas of Early Printing. University of Iowa, 2006, https: / / atlas.lib.uiowa.edu.

Rasmussen, Eric, and Anthony James West. The Shakespeare First Folios: A Descriptive Catalogue. Basingstoke: Palgrave Macmillan, 2012.

Richards, Jennifer and Richard Wistreich, eds. Voicing Texts, 1500-1800. Special Issue of Huntington Library Quarterly 82 (2019).

Stallybrass, Peter. "'Little Jobs": Broadsides and the Printing Revolution'. In Agent of Change: Print Culture Studies after Elizabeth L. Eisenstein, edited by Sabrina Alcorn Baron, Eric N. Lindquist, and Eleanor F. Shevlin. Amherst and Boston: University of Massachusetts Press, 2007, 315-341.

Vanhulst, Henri. 'Suppliers and Clients of Christopher Plantin, Distributor of Polyphonic Music in Antwerp (1566-1578)'. In Musicology and Archival Research: Colloquium Proceedings, 22-23.4.1993, edited by Barbara Haggh, Frank Daelemans, and André Vanrie. Brussels: Archives générales du Royaume, 1994, 558-604.

van Orden, Kate. 'Josquin, Renaissance Historiography, and the Cultures of Print'. In The Oxford Handbook to the New Cultural History of Music, edited by Jane Fair Fulcher. New York: Oxford University Press, 2011, 354-380.

van Orden, Kate. Materialities: Books, Readers, and the Chanson in Sixteenth-Century Europe. New York: Oxford University Press, 2015.

van Orden, Kate. Music, Authorship, and the Book in the First Century of Print. Berkeley: University of California Press, 2014.

van Orden, Kate. 'Robert Granjon and Music during the Golden Age of Typography'. In Music in Print and beyond: Hildegard von Bingen to the Beatles, edited by Craig Monson and Roberta M. Marvin. Rochester, NY: University of Rochester Press, 2013, 11-35.

Vervliet, Hendrik D. L. The Palaeotypography of the French Renaissance: Selected Papers on SixteenthCentury Typefaces. 2 vols. Leiden, Netherlands: Brill, 2008.

Voet, Leon. The Golden Compasses: A History and Evaluation of the Printing and Publishing Activities of the Officina Plantiniana at Antwerp in Two Volumes. Amsterdam: Vagendt, 1969-1972. 